\title{
Pengaruh Panitas yang Berbeda terhadap Produktivitas Induk Kambing Kacang di Desa Sawohan Kecamatan Buduran Kabupaten Sidoarjo
}

\section{(The Effect of Different Parity on the Produc tivity of Kacang Does in Sawohan Village, Buduran, Sidoarjo)}

\author{
Furqon A, Athif IR, Septian WA, Nugraha CD, Putri RF, Suyadi \\ Fakultas Peternakan, Universitas Brawijaya, Malang \\ suyadi2008@yahoo.com
}

\begin{abstract}
Kacang goat is one of goat breeds in Indonesia that has good reproduction in marginal environment and has good prolification. The purpose of this study was to know productivity of Kacang goats based on different parity in Sawohan village, Buduran, Sidoarjo. The total Kacang goats used in this study were 204 does. The variable of productiviy consists of litter size, gestation period, mortality, days open, and kidding interval. Data were collected from recording and questionairre interview. This results showed that a signifant different of litter size and mortality were found on Kacang goats $(\mathrm{P}<0.05)$. The increasing of parity was followed by increasing of litter size start from parity 4 to parity 8 . The fluctuation of mortality was found in parity 1 to parity 6 and the highest was in parity 7 and the lowest was in parity 8 . Gestation period, days open, kidding interval were not significant different among parities $(\mathrm{P}>0.05)$. The highest productivity of the Kacang goats was in parity 7 .
\end{abstract}

Key words: Kacang goats, parity, productivity, gestation period

\begin{abstract}
ABSTRAK
Kambing kacang merupakan salah satu jenis kambing di Indonesia mampu berproduksi pada lingkungan yang kurang baik dan tergolong ternak dengan prolifikasi sedang. Tujuan penelitian ini adalah mengetahui produktivitas induk kambing Kacang berdasarkan paritas yang berbeda di Desa Sawohan Kecamatan Buduran, Sidoarjo. Kambing Kacang yang digunakan dalam penelitian ini adalah 204 ekor. Variabel produktivitas induk yang diamati meliputi litter size, lama kebuntingan, mortalitas, waktu kosong dan kidding interval. Variabel diamati pada paritas ke-1 hingga paritas ke-8. Data dikumpul berdasarkan recording dan kuisioner. Hasil penelitian menunjukkan perbedaan nyata ditemukan pada litter size dan mortalitas Kambing Kacang pada paritas yang berbeda $(\mathrm{P}<0,05)$. Peningkatan paritas meningkatkan jumlah liter size dimulai dari paritas ke-4 hingga paritas ke-8. Fluktuasi tingkat kematian ditemukan pada paritas ke-1 hingga ke-6 dengan angka tertinggi berada pada paritas ke-7 dan terendah pada paritas ke-8. Lama kebuntingan, waktu kosong, dan kidding interval tidak berbeda nyata pada setiap paritas $(\mathrm{P}>0,05)$. Produktivitas tertinggi induk Kambing Kacang terdapat pada paritas ke-5.
\end{abstract}

Kata kunci: Kambing kacang, paritas, produktivitas, lama kebuntingan

\section{PENDAHULUAN}

Berdasarkan data dari Ditjen PKH (2017), konsumsi masyarakat Indonesia dalam pemenuhan kebutuhan sumber protein hewani masih tergolong sangat rendah meskipun 
terdapat peningkatan dari tahun ke tahun. Peningkatan jumlah penduduk Indonesia menyebabkan meningkatnya kebutuhan protein hewani terutama yang berasal dari daging. Konsumsi protein hewani asal daging tersebut memacu meningkatnya peluang bisnis dan ekonomi dalam sub sektor peternakan dengan meningkatkan populasi ternak seperti kambing.

Kambing merupakan salah satu ternak ruminansia kecil yang sangat popular di masyarakat, dengan pemeliharaan yang tergolong mudah. Ada beberapa kelebihan yang didapatkan peternak salah satunya nilai ekonomis dalam pemeliharaan kambing dikarenakan waktu dewasa kelamin yang tergolong cepat (6-8 bulan) sehingga memiliki keuntungan ekonomis yang cukup tinggi. Kambing Kacang merupakan kambing tipe pedaging yang memiliki ciri-ciri bewarna gelap atau coklat, telinga kecil dan berdiri tegak serta memiliki tanduk baik jantan maupun betina. Kambing Kacang memiliki kemampuan hidup dan lahir sampai sapih 79,4\%, sifat prolifik anak kembar dua 52,2\%, kembar tiga 2,6\% dan anak tunggal 44,9\%. Kambing Kacang dewasa kelamin rata-rata umur 307,72 hari, persentase karkas 44-51\%. Rata-rata bobot anak lahir 3,28 kg dan bobot sapih (umur 90 hari) sekitar 10,12 kg (Pamungkas et al. 2009). Berdasarkan keunggulan tersebut, kambing Kacang banyak dikembangkan sebagai usaha sampingan oleh peternak kecil.

Data Ditjen PKH (2017) menyatakan bahwa populasi kambing di Jawa Timur mulai tahun 2014 sampai 2016 terus mengalami kenaikan dengan jumlah kambing berturutturut 3.090.159 ekor, 3.178.197 ekor dan 3.267.954 ekor. Data yang diperoleh dari Badan Pusat Statistik Provinsi Jawa Timur (2016) menyatakan bahwa pada 2016 populasi kambing di wilayah Sidoarjo berjumlah 31.617 ekor, dimana sebanyak 2000 ekor berada di Kecamatan Buduran. Desa Sawohan merupakan salah satu Desa di Kecamatan Buduran yang menjadi sentra peternakan Kambing Kacang.

Data dan informasi yang objektif, diperlukan dalam upaya meningkatkan produktifitas ternak kambing untuk menunjang pembangunan dan perkembangan peternakan khususnya pada ternak kambing. Uraian masalah di atas dikaji dalam sebuah penelitian dengan tujuan untuk mengetahui produktivitas induk dari kambing Kacang berdasarkan paritas (banyaknya kelahiran hidup) yang berbeda di Desa Sawohan Kecamatan Buduran, Sidoarjo.

\section{MATERI DAN METODE}

\section{Lokasi dan waktu peneltian}

Penelitian ini telah dilaksanakan di peternakan rakyat kambing Kacang yang berada di Desa Sawohan, Kecamatan Buduran, Kabupaten Sidoarjo sebagai sentra peternakan kambing Kacang yang dilaksanakan pada bulan Januari 2018 sampai dengan Februari 2018.

\section{Materi penelitian}

Materi yang telah digunakan dalam penelitian ini adalah kambing Kacang yang dimiliki oleh 12 peternak di Desa Sawohan, Kecamatan Buduran, Kabupaten Sidoarjo, sebanyak 204 ekor kambing Kacang. Ternak penelitian terdiri dari paritas ke-1 yaitu 155 ekor, paritas ke-2 yaitu 109 ekor, paritas ke-3 yaitu 75 ekor, paritas ke-4 yaitu 46 ekor, paritas ke-5 yaitu 27, paritas ke-6 yaitu 19 ekor, paritas ke-7 yaitu 12 ekor dan paritas ke8 yaitu 6 ekor. 


\section{Metode penelitian}

Metode yang digunakan dalam penelitian ini adalah metode studi kasus dan data yang diambil adalah data sekunder dari catatan recording produktivitas induk kambing kacang di Desa Sawohan, Kecamatan Buduran, Sidoarjo. Pengambilan sampel dilakukan dengan purpose sampling (secara sengaja) dan dilanjutkan dengan one way anova dan dilanjutkan dengan uji duncan apabila berbeda nyata untuk membandingkan hasil dari masing-masing paritas.

Faktor yang digunakan paritas (P) yang tersedia dibagi antara lain (P1) kambing Kacang paritas 1, (P2) kambing Kacang paritas 2, (P3) kambing kacang paritas 3 dan diteruskan sampai paritas yang tersedia. Beberapa variabel yang diamati dalam penelitian ini adalah litter size, days open, mortalitas anak periode pra sapih, lama kebuntingan, kidding interval dan bobot sapih.

\section{Analisis data}

Data diolah dengan menggunakan Microsoft Excel, kemudian dianalisis dengan menggunakan analisis ragam (ANOVA) dengan one way anova, jika terdapat perbedaan yang nyata atau sangat nyata maka akan dilanjutkan dengan uji Duchan. Data yang diperoleh ditabulasi, dianalisis secara deskriptif kemudian dihitung rata-rata dan standar deviasinya serta dilakukan perhitungan indeks produktivitasnya, dengan menggunakan rumus sesuai petunjuk Amir \& Knipscheer (1989).

\section{HASIL DAN PEMBAHASAN}

Hasil penelitian menunjukkan bahwa rata-rata litter size kambing Kacang di Desa Sawohan yaitu, pada Paritas 1 mengalami peningkatan hingga Paritas 6 dan mengalami penurunan pada Paritas 7 dan Paritas 8 (Tabel 1). Berdasarkan analisis ragam pengaruh paritas yang berbeda terhadap jumlah anak perkelahiran $(\mathrm{P}<0,05)$ menunjukkan paritas ke- 1 dan paritas ke-6 sangat berbeda nyata, paritas ke-2 berbeda nyata dengan paritas ke3, 4, 5, 7 dan 8 .

Menurut Sudewo \& Santosa (2012) paritas induk secara nyata berpengaruh terhadap indeks produktivitas induk. Hal tersebut disebabkan dengan bertambahnya umur induk maka jumlah kelahiran akan meningkat. Hal ini sesuai pernyataan Sudewo \& Santosa (2011), bahwa jumlah anak perkelahiran meningkat seiring dengan meningkatnya umur induk. Pada hasil penelitian ini rataan jumlah anak sekelahiran adalah sebesar 1,38 $\pm 0,49$ ekor. Hasil ini lebih tinggi dibandingkan pada penelitan Mahmilia et al. (2007), sebesar 1,31 ekor di Loka Penelitian Kambing Potong Sei Putih. Namun, rataan ini sangat berbeda dengan hasil penelitian yang telah dilakukan di Jawa Tengah oleh Sodiq \& Sumaryadi (2002), yang menunjukkan bahwa rata-rata jumlah anak perkelahiran untuk kambing Kacang 2,06. Berdasarkan rataan tersebut, Kambing Kacang termasuk ternak yang prolific yang dapat melahirkan lebih dari satu ekor anak dalam sekali beranak, kelahiran kembar dua atau tiga. 
Tabel 1. Pengaruh paritas yang berbeda pada litter size, lama kebuntingan dan mortalitas

\begin{tabular}{lcccc}
\hline Paritas & Jumlah ternak (n) & $\begin{array}{c}\text { Litter size } \\
\text { (ekor) }\end{array}$ & $\begin{array}{c}\text { Lama kebuntingan } \\
\text { (bulan) }\end{array}$ & Mortalitas (\%) \\
\hline Paritas 1 & 155 & $1,02 \pm 0,15^{\mathrm{a}}$ & $5,34 \pm 0,64$ & $40,88^{\mathrm{ab}}$ \\
Paritas 2 & 109 & $1,27 \pm 0,44^{\mathrm{ab}}$ & $5,38 \pm 0,52$ & $30,93^{\mathrm{ab}}$ \\
Paritas 3 & 75 & $1,36 \pm 0,15^{\mathrm{bc}}$ & $5,48 \pm 0,10$ & $35,29^{\mathrm{ab}}$ \\
Paritas 4 & 46 & $1,34 \pm 0,48^{\mathrm{bc}}$ & $5,32 \pm 0,52$ & $35,48^{\mathrm{ab}}$ \\
Paritas 5 & 27 & $1,48 \pm 0,50^{\mathrm{bc}}$ & $5,37 \pm 0,49$ & $20,00^{\mathrm{ab}}$ \\
Paritas 6 & 19 & $1,57 \pm 0,60^{\mathrm{c}}$ & $5,31 \pm 0,47$ & $30,00^{\mathrm{ab}}$ \\
Paritas 7 & 12 & $1,50 \pm 0,67^{\mathrm{bc}}$ & $5,33 \pm 0,49$ & $44,44^{\mathrm{b}}$ \\
Paritas 8 & 6 & $1,50 \pm 0,54^{\mathrm{bc}}$ & $5,16 \pm 0,40$ & $11,11^{\mathrm{a}}$ \\
\hline Rata-rata & & $1,38 \pm 0,49$ & $5,33 \pm 0,45$ & 34,34 \\
\hline
\end{tabular}

Tabel 2. Pengaruh paritas yang berbeda pada waktu kosong dan kidding interval

\begin{tabular}{lccc}
\hline \hline Paritas & Jumlah ternak (n) & Waktu kosong (bulan) & Kidding interval (bulan) \\
\hline Paritas 2 & 109 & $2,74 \pm 1,28$ & $7,97 \pm 1,66$ \\
Paritas 3 & 75 & $2,76 \pm 1,02$ & $8,09 \pm 1,06$ \\
Paritas 4 & 46 & $2,65 \pm 1,01$ & $7,82 \pm 1,62$ \\
Paritas 5 & 27 & $2,70 \pm 1,13$ & $8,03 \pm 1,34$ \\
Paritas 6 & 19 & $3,15 \pm 1,53$ & $8,15 \pm 2,40$ \\
Paritas 7 & 12 & $3,33 \pm 1,61$ & $8,50 \pm 1,78$ \\
Paritas 8 & 6 & $3,16 \pm 1,16$ & $8,33 \pm 1,03$ \\
\hline
\end{tabular}

Berdasarkan Tabel 1, pengaruh perbedaan paritas ditemukan tidak berbeda nyata terhadap lama kebuntingan $(\mathrm{P}>0,05)$. Rata-rata kebuntingan ternak kambing Kacang pada penelitian ini yaitu 5,33 $\pm 0,45$ atau sekitar 161 hari, dengan lama kebuntingan tertinggi pada paritas ke-3 dan terendah pada paritas ke-8. Hal yang sama dilaporkan juga oleh Sudewo et al. (2012), menyatakan bahwa penilaian lama bunting pada paritas yang berbeda menunjukkan nilai bahwa tidak berbeda nyata $(\mathrm{P}>0,05)$. Ada beberapa faktor yang mempengaruhi lama kebuntingan diantaranya paritas, genetik, hormonal dan lingkungan. Selain itu jumlah anak yang dikandung sangat mempengaruhi lama bunting seekor ternak, kambing beranak kembar mempunyai lama bunting yang lebih pendek dibandingkan yang beranak tunggal (Novita et al. 2006).

Persentase kematian kambing Kacang terdapat pada paritas ke-7 sebesar 44,44\% dan pada paritas ke- 8 sebesar 11,11\% (Tabel 1). Berdasarkan analisis ragam pengaruh paritas yang berbeda terhadap mortalitas ternak pada paritas ke-1 sampai paritas ke-5 ( $>>0,05)$ tidak ditemukan perbedaan yang nyata. Namun, mortalitas pada paritas ke-7 dan paritas ke-8 menunjukkan perbedaan yang nyata $(\mathrm{P}<0,05)$. Beberapa kejadian yang sering ditemui di lapang saat penelitian berlangsung adalah tingginya mortalitas disebabkan polio pada umur 1 bulan ke bawah. Keadaan kandang yang dikelilingi oleh tambak menjadi salah satu faktor dari banyaknya anak kambing yang terjebur sehingga meningkatkan angka mortalitas. 
Days Open atau masa kosong adalah lama waktu setelah induk melahirkan sampai bunting kembali. Menurut Sumadi (2001), masa kosong adalah jangka waktu sejak kambing beranak sampai dikawinkan kembali dan terjadi kebuntingan. Hasil penelitian menunjukkan bahwa rata-rata waktu kosong dari kambing di peternakan Oro-Oro Dowo yaitu 2,56 $\pm 1,09$ bulan atau sekitar 79,5 hari dengan analisis ragam pengaruh paritas terhadap waktu kosong ternak $(\mathrm{P}>0,05)$ tidak berbeda nyata (Tabel 2). Days open pada seekor ternak dipengaruhi oleh beberapa faktor diantaranya kesehatan induk, fertilitas induk, dan manajemen meliputi recording, ketepatan dalam deteksi estrus dan nilai nutrisi yang cukup (Hafez \& Hafez 2008).

Berdasarkan Tabel 2, hasil penelitian tidak menunjukkan adanya pengaruh perbedaan paritas terhadap kidding interval $(\mathrm{P}>0,05)$. Berdasarkan hasil penelitian selang

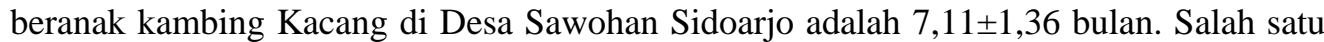
penyebab tingginya selang beranak adalah tidak tepatnya waktu mengawinkan karena sistem perkawinan IB lebih efektif dibandingkan kawin alami (Hartatik et al. 2009). Berdasarkan keadaan di lapang, ketidaktahuan peternak dan keterbatasan waktu untuk mengurus ternak menyebabkan ketidakpastian pada waktu selang beranak. Hal ini dapat mempengaruhi lama waktu selang beranak kambing Kacang.

\section{KESIMPULAN}

Litter size dan mortilitas kambing Kacang ditemukan berbeda nyata akibat adanya pengaruh perbedaan paritas. Peningkatan paritas meningkatkan jumlah litter size dimulai dari paritas ke-4 hingga paritas ke-8. Fluktuasi tingkat kematian ditemukan pada paritas ke-1 hingga ke-6 dengan angka tertinggi berada pada paritas ke-7 dan terendah pada paritas ke-8. Pengaruh perbedaan paritas tidak ditemukan pada lama kebuntingan, waktu kosong, dan kidding interval.

\section{DAFTAR PUSTAKA}

Amir P, Knipscheer HC. 1989. Conducting on-farm animaal research: Procedures and economic analysis. Winrock Int Inst Agric Dev Itn Dev Res Centre. Singapore: Singapore National Printers Ltd.

Badan Pusat Statistik [BPS]. 2016. Populasi ternak di Jawa Timur. Jakarta (Indonesia): Badan Pusat Statistik.

[Ditjen PKH] Direktorat Jendral Peternakan dan Kesehatan Hewan. 2017. Statistik peternakan dan kesehatan hewan. Jakarta (Indonesia): Kementerian Pertanian Republik Indonesia.

[Ditjen PKH] Direktorat Jendral Peternakan dan Kesehatan Hewan. 2016. Statistik peternakan dan kesehatan hewan. Jakarta (Indonesia): Kementerian Pertanian Republik Indonesia.

Hafez B, Hafez ESE. 2008. Fertilization and cleavage. In: Hafez B, Hafez ESE. Reproduction in Farm Animals. 7th ed. Oxford (UK): Hafez Blackwell Publishing. p. 110-125.

Hartatik T, Mahardika DA, Widi TSM, Baliarti E. 2009. Karakteristik dan kinerja induk sapi silangan Limousin-Madura dan Madura di Kabupaten Sumenep dan Pamekasan. Buletin Peternakan. 33:143-147.

Mahmilia F, Pamungkas FA, Elieser S. 2008. Lama bunting, bobot lahir dan daya hidup pra sapih kambing Boerka-1 (50B;50K) berdasarkan: jenis kelamin, tipe lahir dan paritas. Prosiding Seminar Nasional Teknologi Peternakan dan Veteriner. Bogor (Indonesia): Pusat Penelitian dan Pengembangan Peternakan. hlm. 386-390. 
Novita CI, Sudono A, Sutama IK, Toharmat T. 2009. Produktivitas kambing Peranakan Etawah yang diberi ransum berbasis jerami padi fermetasi. Media Peternakan. 29:96106.

Pamungkas FA, Batubara A, Doloksaribu M, Sihite E. 2009. Potensi beberapa plasma nutfah kambing lokal Indonesia: Petunjuk teknis. Bogor (Indonesia): Pusat Penelitian dan Pengembangan Peternakan.

Sodiq A, Sumaryadi MY. 2002. Reproductive performance of kacang and peranakan etawah goat in Indonesia. J Anim Prod. 42:52-59.

Sudewo, Ari, Santoso SA. 2012. Poduktivitas kambing peranakan etawah berdasarkan litter size, tipe kelahiran dan mortalitas di village bredding centre Kabupaten Banyumas. Prosiding Seminar Nasional Fakultas Peternakan Universitas Jendral Sudirman. Purwokerto (Indonesia): Universitas Jendral Sudirman.

Sudewo AT, Santosa SA. 2011. Analisis sumberdaya genetik kambing peranakan etawah di village breeding centre Kabupaten Banyumas. Prosiding Seminar Nasional Pengembangan Sumberdaya Pedesaan dan Kearifan Lokal Berkelanjutan. Purwokerto (Indonesia): Universitas Jendral Sudirman.

Sumadi. 2001. Estimasi dinamika populasi dan output kambing peranakan etawah di Desa Cibening Kecamatan Purwakarta [Tesis]. [Bogor (Indonesia)]: Institut Pertanian Bogor. 